\title{
Konseling Menyusui Eksklusif on Demand Terhadap Involusi Uteri pada Akseptor IUD Post Plasenta
}

\author{
Indah Purnamasari ${ }^{1 *}$, Lia Ayu Kusumawardani ${ }^{2 *}$ \\ 1, 2 Sekolah Tinggi Ilmu Kesehatan Guna Bangsa, DI Yogyakarta, Indonesia \\ *indahpurnamasari30912@gmail.com, lia.ak@gunabangsa.ac.id
}

\section{ARTICLE INFO}

Article history:

Received February 17,2022

Accepted February 26, 2022

Published February 26, 2022

\section{Kata Kunci:}

Konseling

Menyusui on Demand

Involusi Uteri

IUD Post Plasenta

Key words:

Counseling

On Demand Breasfeeding

Involutary Utery

IUD Post Plasenta

DOI:

https://10.48092/jik.v8i2.167

\section{ABSTRAK}

Latar Belakang: Konseling yang diberikan tenaga kesehatan kepada akseptor KB IUD mengenai ASI on demand dapat mempengaruhi pengetahuan, sikap dan perilaku akseptor KB IUD terhadap pemberian ASI eksklusif on demand. Penelitian ini bertujuan mengetahui pengaruh konseling tentang menyusui on demand terhadap involusi uteri pada akseptor IUD post plasenta. Metodequasi eksperimental dengan desain penelitian static group comparison. Populasi pada penelitian ini adalah semua ibu yang menggunakan IUD post plasenta berjumlah 51 orang. Teknik pengambian sampel purposive sampling. Instrumen yang digunakan adalah kuesioner, modul dan leaflet menyusui ASI on demand. Analisis data menggunakan uji anova dan ancova. Hasil: rata-rata TFU pada akseptor IUD post plasenta pada kelompok intervensi konseling adalah 8,39, rata-rata TFU kelompok control leaflet 8,03 dan rata-rata TFU kelompok tanpa perlakuan 7,92. Hasil uji anoca didapatkan nilai p-value $0,002<0,05$. Kesimpulannya ada pengaruh konseling tentang menyusui on demand terhadap involusi uteri pada akseptor IUD post plasenta. Kesimpulan: Ada perbedaan involusi uteri pada kelompok konseling, leaflet dan tanpa perlakuan pada akseptor IUD post plasenta. Ada perbedaan involusi uteri pada kelompok konseling, leaflet dan tanpa perlakuan dengan kovarian pengetahuan, sikap dan perilaku pada akseptor IUD post plasenta.

\section{ABSTRACT}

Exclusive Breastfeeding Counseling on Demand Against Uterine Involution in Post Placenta IUD Acceptors

Background: Counseling given by health workers to IUD family planning acceptors regarding breastfeeding on demand can affect the knowledge, attitudes and behavior of IUD family planning acceptors towards exclusive breastfeeding on demand. This study aims to determine the effect of counseling on breastfeeding on demand on uterine involution in post-placental IUD acceptors.methodQuasi experimentalThe population in this study were all 51 mothers who used a post-placental IUD. The sampling technique is purposive sampling. The instruments used were questionnaires, modules and leaflets for breastfeeding on demand. Data analysis used ANOVA and ANOVA tests. Results: the average TFU of postplacental IUD acceptors in the counseling intervention group was 8.39 , the average TFU of the leaflet control group was 8.03 and the average TFU of the untreated group was 7.92. Anoca test results obtained p-value $0.002<0.05$. In conclusion, there is an effect of counseling about breastfeeding on demand on uterine involution in post-placental IUD acceptors. Conclusion: There were differences in uterine involution in the counseling, leaflet and untreated groups on post-placental IUD acceptors. There were differences in uterine involution in the counseling, leaflet and untreated groups with covariance of knowledge, attitude and behavior in post-placental IUD acceptors.

Thisopenaccessarticleisunderthe CC-BY-SAlicense. 


\section{PENDAHULUAN}

Selama kurun waktu 25 tahun yaitu 1990 sampai dengan 2015, WHO memperkirakan 10,7 juta perempuan telah meninggal karena melahirkan. Pada tahun 2015, sebanyak 303.000 kematian ibu terjadi di seluruh dunia. Kematian wanita usia subur di negara miskin diperkirakan sekitar $25-50 \%$ penyebabnya adalah masalah kesehatan, persalinan, dan nifas. AKI masih merupakan masalah kesehatan yang serius di negara berkembang. Menurut laporan World Health Organization (WHO), tahun 2014 beberapa negara memiliki AKI cukup tinggi seperti Afrika Sub-Saharan 179.000 jiwa, Asia Selatan 69.000 jiwa, dan Asia Tenggara 16.000 jiwa (WHO, 2015).

Angka kematian ibu di negara-negara Asia Tenggara urutan pertama ditempat oleh Laos dengan angka kematian 357 per 100 ribu. Bila dibandingkan dengan tetangga terdekat, yaitu Singapura dan Malaysia, jumlah kematian ibu melahirkan di Indonesia masih sangat besar. Singapura pada tahun 2015 memiliki angka kematian ibu melahirkan tujuh per 100 ribu, dan Malaysia di angka 24 per 100 ribu (Marzuki, 2018). Angka kematian ibu di Indonesia belum mencapai target yang telah ditentukan oleh pemerintah. Berdasarkan data SDKI (2012) angka kematian ibu mencapai 359 kematian ibu per 100.000 kelahiran hidup. Data (BPS, 2016) ditinjau dari hasil SUPAS 2015 angka kematian ibu di Indonesia mengalami penurunan yaitu 346 kematian ibu per 100.000 kelahiran hidup.

Jumlah kematian ibu di DIY tahun 2014 (40 ibu) mengalami penurunan dibandingkan dengan tahun 2013 (46 ibu). Pada tahun 2015 penurunan jumlah kematian ibu sangat siknifikan hingga menjadi sebesar 29 kasus. Namun pada tahun 2016 kembali naik tajam menjadi 39 kasus dan kembali sedikit turun menjadi 34 pada tahun 2017. Kasus terbanyak terjadi di Kabupaten Gunung Kidul (12 kasus) dan terendah di Kabupaten Kulon Progo (3 kasus) (DIY, 2017).

Menurut Kemenkes RI (2014) penyebab kematian ibu langsung yaitu perdarahan, hipertensi dalam kehamilan, infeksi, partus lama/macet, abortus, dan lain-lain. Penyebab kematian ibu terbesar masih tetap sama yaitu perdarahan, sedangkan partus lama merupakan penyumbang kematian ibu terendah. Penyebab tidak langsung yang menyebabkan kematian ibu, seperti pendidikan, sosial ekonomi, empat terlalu dan tiga terlambat. Berdasarkan uraian di atas dapat disimpulkan bahwa tingginya angka kematian ibu akibat penyebab langsung maupun penyebab lain atau tidak langsung menuntut peran besar tenaga kesehatan dalam menangani penyebab tersebut sehingga dapat tedeteksi secara dini dan dapat menyelamatkan ibu maupun bayinya.

Salah satu penyebab terjadinya perdarahan pasca post partum adalah subinvolusi. Penyebab subinvolusi atau kegagalan rahim untuk kembali ke keadaan semula seperti keadaan tidak hamil adalah adanya infeksi dan sisa plasenta (Sunarsih, 2013). Subinvolusi merupakan salah satu penyebab terjadinya perdarahan postpartum yang merupakan penyebab tertinggi kematian ibu (Saleha, 2013).

Subinvolusi uterus terjadi karena adanya sisa plasenta dan infeksi (Sunarsih, 2013). Subinvolusi uterus menyebabkan kontraksi uterus menurun sehingga pembuluh darah yang lebar tidak menutup sempurna sehingga pendarahan terjadi terus menerus. Pada pemeriksaan bimanual di temukan uterus lebih besar dan lebih lembek dari seharusnya, fundus masih tinggi, lochea banyak dan berbau, dan tidak jarang terdapat pula perdarahan (Prawirohardjo, 2010).

Salah satu cara untuk menunda kehamilan dan menekan angka pertumbuhan penduduk yakni melalui program Keluarga Berencana (KB) (BPS, 2016). Program $\mathrm{KB}$ memiliki peranan dalam menurunkan resiko kematian ibu melalui pencegahan kehamilan, penundaan usia kehamilan serta mejarangkan kehamilan dengan sasaran utama adalah ibu nifas. Program KB yang paling efektif adalah kontrasepsi IUD post plasenta (BKKBN, 2013).

Meskipun sudah ada berbagai cara baik secara global maupun nasional, upaya untuk meningkatkan kesehatan ibu salah satunya dengan cara penggunan alat kontrasepsi jangka panjang seperti IUD post plasenta, tetapi mortalitas pada ibu masih menjadi perhatian yang utama. Saat ini semakin tinggi resiko kehamilan yang tidak diinginkan yaitu $35 \%$ di seluruh dunia, dengan alat kontrasepsi mampu menurunkan 20-35\% kematian maternal (Machiyama, Kazuyo and John, 2014). Setelah melahirkan perempuan membutuhkan kontrasepsi yang efektif dan efisien yang aman digunakan dalam waktu yang cukup lama seperti IUD, sebuah penelitian mengevaluasi bahwa kontrasepsi yang efektif bagi perempuan setelah melahirkan yaitu menggunakan IUD (Kittur, 2012).

Upaya untuk mengendalikan involusi post partum, pemerintah mengeluarkan program dan kebijakan teknis, yaitu setidaknya dilakukan 4x kunjungan masa nifas untuk menilai status ibu dan BBL, dan untuk mencegah, mendeteksi menangani masalah-masalah yang terjadi, salah satunya masalah yang dipantau pada ibu nifas (KF) adalah involusi uteri. Diantara program dan kebijakan adalah senam nifas, peningkatan gizi ibu nifas, inisiasi menyusui dini (IMD) dan mobilisasi dini (Munayarokh, 2015).

Konseling yang diberikan tenaga kesehatan kepada akseptor KB IUD mengenai ASI on demand dapat mempengaruhi pengetahuan, sikap dan perilaku akseptor KB IUD terhadap pemberian ASI eksklusif on demand. Penelitian yang dilakukan oleh Azzahra (2015) dan Yanti, dkk (2018) mengungkapkan bahwa konseling berpengaruh terhadap pengetahuan, sikap dan perilaku seseorang dimana peningkatan pengetahuan dan sikap secara signifi kan terjadi pada kelompok ibu yang mendapatkan konseling.

Berdasarkan hasil studi pendahuluan yang dilakukan di kabupaten Gunung kidul didapatkan informasi bahwa peserta IUD masih tergolong rendah yaitu 51,26\% lebih rendah dibandingkan kabupaten lain di wilayah DIY. Data 3 bulan terakhir yaitu bulan Oktober sampai dengan bulan Desember 2018 diketahui rata-rata jumlah akseptor IUD adalah 30 orang dengan rincian rata-rata di Puskesmas Pathuk 1 sebanyak 5 orang, Puskesmas Nglipar 1 sebanyak 5 orang, Puskesmas Playen 1 sebanyak 5 orang, Puskesmas Wonosari 1 sebanyak 5 orang, Puskesmas Semin 1 dan Puskesmas Ponjong 1 sebanyak 5 orang.

Hasil wawancara dengan 10 orang akseptor $\mathrm{KB}$ IUD yang kunjungan, didapatkan informasi bahwa 7 orang (70\%) melakukan IMD namun tidak menyusui on demand dan 3 orang lainnya melakukan IMD dan menyusui on demand. Akseptor IUD tersebut, dari 10 orang, 6 orang $(60 \%)$ mengalami subinvolusi uteri sehingga mengalami perdarahan lebih lama dan 4 orang lainnya (40\%) tidak mengalami subinvolusi uteri. 
Penelitian bertujuan untuk mengetahui pengaruh konseling tentang menyusui on demand terhadap involusi uteri pada akseptor IUD post plasenta.

\section{METODE}

Desain penelitian adalah quasi eksperimental dengan desain penelitian static group comparison. Penelitian dilakukan di puskesmas wilayah Kabupaten Gunungkidul pada bulan Agustus 2019. Populasi pada penelitian ini adalah semua ibu yang menggunakan IUD post plasenta di kabupaten Gunungkidul berjumlah 51 orang. Teknik pengambian sampel purposive sampling. Kriteria inklusi: Ibu post partum akseptor IUD, melakukan IMD, mendapatkan ijin dari suami/keluarga, umur 25-45 tahun, tidak memiliki riwayat komplikasi kehamilan atau persalinan, persalinan normal. Kriteria eksklusi: dalam kegawatdaruratan dan tidak bersedia menjadi responden. Variable bebas konseling dan variabel terikat involusi uteri. Instrumen yang digunakan adalah kuesioner, modul dan leaflet menyusui ASI on demand. Analisis data menggunakan uji anova dan ancova.

\section{HASIL DAN PEMBBAHASAN}

\section{Karakteristik responden}

Karakteristik responden dalam penelitian ini meliputi umur, pendidikan, pekerjaan, paritas dan penghasilan. Responden dalam penelitian ini dikelompokkan menjadi 3 yaitu kelompok intervensi yaitu kelompok yang diberi konseling tentang ASI on demand, kelompok kontrol yaitu kelompok yang diberi leaflet tentang ASI on demand dan kelompok yang tidak diberi perlakuan. Deskripsi karakteristik responden dapat diperlihatkan pada tabel berikut:

Tabel 1.

Distribusi Frekuensi Karakteristik Responden

\begin{tabular}{|c|c|c|c|c|c|c|c|}
\hline \multirow[t]{2}{*}{ No. } & \multirow[t]{2}{*}{ Karakteristik } & \multicolumn{2}{|c|}{ Intervensi } & \multicolumn{2}{|c|}{ Kontrol } & \multicolumn{2}{|c|}{$\begin{array}{c}\text { Tanpa } \\
\text { Perlakuan }\end{array}$} \\
\hline & & $f$ & $\%$ & $f$ & $\%$ & $\mathrm{f}$ & $\%$ \\
\hline \multirow[t]{4}{*}{1.} & Pendidikan & & & & & & \\
\hline & a. SLTP & 5 & 29,4 & 4 & 23,5 & 2 & 11,8 \\
\hline & b. SLTA & 11 & 64,7 & 9 & 52,9 & 7 & 41,2 \\
\hline & c. PT & 1 & 5,9 & 4 & 23,5 & 8 & 47,1 \\
\hline \multirow[t]{4}{*}{2.} & Pekerjaan & & & & & & \\
\hline & a. IRT & 11 & 64,7 & 10 & 58,8 & 7 & 41,2 \\
\hline & b. Karyawan & 4 & 23,5 & 7 & 41,2 & 9 & 52,9 \\
\hline & c. Wiraswasta & 2 & 11,8 & & & 1 & 5,9 \\
\hline \multirow[t]{5}{*}{3.} & Umur & & & & & & \\
\hline & a. $25-30$ tahun & 12 & 70,6 & 12 & 70,6 & 4 & 23,5 \\
\hline & b. $31-35$ tahun & 4 & 23,5 & 4 & 23,5 & 5 & 29,4 \\
\hline & c. $36-40$ tahun & 1 & 5,9 & 1 & 5,9 & 5 & 29,4 \\
\hline & d. $41-45$ tahun & & & & & 3 & 17,6 \\
\hline \multirow[t]{3}{*}{4.} & Paritas & & & & & & \\
\hline & a. Primipara & 6 & 35,3 & 10 & 58,8 & 9 & 52,9 \\
\hline & b. Multipara & 11 & 64,7 & 7 & 41,2 & 8 & 47,1 \\
\hline \multirow[t]{3}{*}{5.} & Penghasilan & & & & & & \\
\hline & a. $1-2$ juta & 11 & 64,7 & 11 & 64,7 & 13 & 76,5 \\
\hline & b. $>2$ juta & 6 & 35,3 & 6 & 35,3 & 4 & 23,5 \\
\hline
\end{tabular}

tangga (IRT) yaitu 11 orang $(64,7 \%)$, berumur antara 25-30 tahun yaitu 12 orang $(70,6 \%)$, multipara yaitu 11 orang $(64,7 \%)$ dan mempunyai penghasilan 1-2 juta yaitu 11 orang (64,7\%). Sebagian besar kelompok kontrol berpendidikan SLTA yaitu 9 orang $(52,9 \%)$, bekerja sebagai ibu rumah tangga (IRT) yaitu 10 orang $(58,8 \%)$, berumur antara 25-30 tahun yaitu 12 orang (70,6\%), primipara yaitu 10 orang $(58,8 \%)$ dan mempunyai penghasilan 1-2 juta yaitu 11 orang $(64,7 \%)$. Sebagian besar kelompok tanpa perlakuan berpendidikan PT yaitu 8 orang $(47,1 \%)$, bekerja swasta yaitu 8 orang $(47,8 \%)$, berumur antara 25-30 tahun dan berumur antara 36-40 tahun yaitu 5 orang $(29,4 \%)$, primipara yaitu 9 orang $(52,9 \%)$ dan mempunyai penghasilan 1-2 juta yaitu 13 orang (76,5\%).

\section{Perbedaan pengetahuan, sikap dan perilaku terhadap pemberian ASI on demand setelah diberikan konseling ASI eksklusif on demand}

Tabel 2.

Perbedaan pengetahuan, sikap dan perilaku terhadap pemberian ASI on demand setelah diberikan konseling ASI eksklusif on demand

\begin{tabular}{|c|c|c|c|c|}
\hline \multirow{2}{*}{$\begin{array}{l}\text { Output } \\
\text { intervensi }\end{array}$} & \multicolumn{3}{|c|}{ Kelompok } & \multirow[b]{2}{*}{$\begin{array}{c}\mathrm{p}- \\
\text { value }\end{array}$} \\
\hline & $\begin{array}{l}\text { Intervensi } \\
\text { (konseling) }\end{array}$ & $\begin{array}{l}\text { Kontrol } \\
\text { (leaflet) }\end{array}$ & $\begin{array}{c}\text { Tanpa } \\
\text { Perlakuan }\end{array}$ & \\
\hline Pengetahuan & $9,65 \pm 0,493$ & $\begin{array}{r}8,94 \pm \\
0,899\end{array}$ & $\begin{array}{r}7,94 \pm \\
1,144\end{array}$ & 0,000 \\
\hline Sikap & $4,71 \pm 0,588$ & $\begin{array}{r}4,00 \pm \\
1,000\end{array}$ & $\begin{array}{r}3,12 \pm \\
1,495\end{array}$ & 0,000 \\
\hline Perilaku & $\begin{array}{r}14,00 \pm \\
1,225\end{array}$ & $\begin{array}{r}13,82 \pm \\
1,811\end{array}$ & $\begin{array}{r}12,76 \pm \\
1,393\end{array}$ & 0,042 \\
\hline
\end{tabular}

Berdasarkan tabel 2. dapat diinterpretasikan bahwa rata-rata pengetahuan ibu tentang ASI on demand pada kelompok intervensi adalah 9,65 lebih tinggi dibandingkan pada kelompok kontrol 8,94 dan pada kelompok tanpa perlakuan 7,94 . Hasil nilai p-value $<0,05$ yang berarti ada perbedaan pengetahuan ibu tentang ASI on demand setelah diberikan konseling ASI eksklusif on demand

Hasil analisis sikap menunjukkan bahwa rata-rata sikap ibu terhadap ASI on demand pada kelompok intervensi adalah 4,71 lebih tinggi dibandingkan pada kelompok kontrol 4,000 dan pada kelompok tanpa perlakuan 3,12. Hasil nilai p-value $<0,05$ yang berarti ada perbedaan sikap ibu terhadap ASI on demand setelah diberikan konseling ASI eksklusif on demand

Hasil analisis penghasilan menunjukkan bahwa ratarata perilaku ibu terhadap ASI on demand pada kelompok intervensi adalah 14,00 pada kelompok kontrol 13,82 dan pada kelompok tanpa perlakuan 12,76 . Hasil nilai p-value < 0,05 yang berarti ada perbedaan perilaku ibu terhadap ASI on demand setelah diberikan konseling ASI eksklusif on demand

Berdasarkan tabel 2. dapat disimpulkan bahwa ada perbedaan pengetahuan, sikap dan perilaku akseptor IUD post plasenta tentang ASI on demand setelah diberikan konseling ASI eksklusif on demand

Berdasarkan tabel 1. diketahui bahwa dari 17 orang, sebagian besar kelompok intervensi berpendidikan SLTA yaitu 11 orang $(64,7 \%)$, bekerja sebagai ibu rumah 
3. Perbedaan Involusi Uteri Pada Akseptor IUD Post Plasenta setelah diberikan konseling ASI eksklusif on demand

Tabel 3.

Perbedaan Involusi Uteri Pada Akseptor IUD Post Plasenta setelah diberikan konseling ASI eksklusif on demand

\begin{tabular}{cccccc}
\hline \multirow{2}{*}{ Observasi } & \multicolumn{3}{c}{ Kelompok } & \multirow{2}{*}{$\begin{array}{c}\text { p- } \\
\text { value }\end{array}$} \\
\cline { 3 - 5 } & $\begin{array}{c}\text { Intervensi } \\
\text { (konselin) }\end{array}$ & $\begin{array}{c}\text { Kontrol } \\
\text { (leaflet) }\end{array}$ & $\begin{array}{c}\text { Tanpa } \\
\text { Perlakuan }\end{array}$ & \\
\hline \multirow{2}{*}{ TFU } & Mean & $8,39 \pm$ & $8,03 \pm$ & $7,92 \pm$ & 0,002 \\
& + SD & 0,395 & 0,330 & 0,425 & \\
\hline
\end{tabular}

Berdasarkan tabel 3. dapat diinterpretasikan bahwa rata-rata TFU pada akseptor IUD post plasenta pada kelompok intervensi adalah 8,39 lebih tinggi dibandingkan pada kelompok kontrol 8,03 dan pada kelompok tanpa perlakuan 7,92. Hasil nilai p-value $<0,05$ yang berarti ada Perbedaan Involusi Uteri Pada Akseptor IUD Post Plasenta setelah diberikan konseling ASI eksklusif on demand.

Selanjutnya untuk mengetahui kelompok mana yang paling besar perbedaannya dilanjutkan dengan uji post hock atau uji Least Significant Differences ( $L S D)$ yang hasilnya adalah sebagai berikut:

Tabel 4

Perbedaan Involusi Uteri Pada Kelompok Konseling, Leaflet Dan Tanpa Perlakuan Pada Akseptor IUD post plasenta di wilayah Kabupaten Gunungkidul

\begin{tabular}{clrr}
\hline $\begin{array}{c}(\mathrm{I}) \\
\text { kelompok }\end{array}$ & $(\mathrm{J})$ kelompok & $\begin{array}{c}\text { Mean } \\
\text { Difference (I-J) }\end{array}$ & P value \\
\hline intervensi & kontrol & 0,353 & 0,010 \\
& tanpa perlakuan & 0,471 & 0,001 \\
\multirow{2}{*}{ kontrol } & tanpa perlakuan & 0,117 & 0,375 \\
\hline
\end{tabular}

Berdasarkan tabel 4. dapat diinterpretasikan bahwa TFU antara kelompok intervensi dengan kelompok kontrol terdapat beda rata-rata 0,353 dengan signifikansi ( $\mathrm{p}$ value) 0,010 sehingga dapat disimpulkan bahwa ada perbedaan yang signifikan antara involusi uteri pada kelompok intervensi dengan kelompok kontrol. TFU antara kelompok intervensi dengan kelompok tanpa perlakuan terdapat beda rata-rata 0,471 dengan signifikansi ( $\mathrm{p}$ value) 0,001 sehingga dapat disimpulkan bahwa ada perbedaan yang signifikan antara involusi uteri pada kelompok intervensi dengan kelompok tanpa perlakuan. TFU antara kelompok kontrol dengan kelompok tanpa perlakuan terdapat beda rata-rata 0,117 dengan signifikansi ( $\mathrm{p}$ value) 0,375 sehingga dapat disimpulkan bahwa tidak ada perbedaan yang signifikan antara involusi uteri pada kelompok kontrol dengan kelompok tanpa perlakuan.

Selanjutnya untuk mengetahui variabel mana yang paling besar perbedaannya dilanjutkan dengan uji post hock atau uji Least Significant Differences ( $L S D)$ yang hasilnya adalah sebagai berikut:
Tabel 5

Perbedaan Involusi Uteri Pada Kelompok Konseling, Leaflet Dan Tanpa Perlakuan Dengan Kovarian Pengetahuan, Sikap Dan Perilaku Pada Akseptor IUD Post Plasenta

\begin{tabular}{|c|c|c|c|c|c|c|}
\hline \multirow{2}{*}{ Konseling } & \multirow{2}{*}{$\begin{array}{c}\text { (I) } \\
\text { kelompok }\end{array}$} & \multirow{2}{*}{ (J) kelompok } & \multirow{2}{*}{$\begin{array}{c}\text { Mean } \\
\text { Differe } \\
\text { nce } \\
(\mathrm{I}-\mathrm{J})\end{array}$} & \multirow{2}{*}{ Sig. } & \multicolumn{2}{|c|}{$\begin{array}{c}95 \% \text { Confidence } \\
\text { Interval }\end{array}$} \\
\hline & & & & & $\begin{array}{l}\text { Lower } \\
\text { Bound }\end{array}$ & $\begin{array}{l}\text { Upper } \\
\text { Bound }\end{array}$ \\
\hline \multirow{3}{*}{$\begin{array}{l}\text { pengetahuan } \\
\text { ASI }\end{array}$} & intervensi & kontrol & $0,706^{*}$ & 0,025 & 0,09 & 1,32 \\
\hline & intervensi & tanpa perlakuan & $1,706^{*}$ & 0,000 & 1,09 & 2,32 \\
\hline & kontrol & tanpa perlakuan & $1,000^{*}$ & 0,002 & 0,39 & 1,61 \\
\hline \multirow[t]{3}{*}{ sikap ASI } & intervensi & kontrol & 0,706 & 0,066 & $-0,05$ & 1,46 \\
\hline & intervensi & tanpa perlakuan & $1,588^{*}$ & 0,000 & 0,83 & 2,34 \\
\hline & kontrol & tanpa perlakuan & $0,882^{*}$ & 0,023 & 0,13 & 1,64 \\
\hline \multirow[t]{3}{*}{ perilaku ASI } & intervensi & kontrol & 0,176 & 0,733 & $-0,86$ & 1,21 \\
\hline & intervensi & tanpa perlakuan & $1,235^{*}$ & 0,020 & 0,20 & 2,27 \\
\hline & kontrol & tanpa perlakuan & $1,059^{*}$ & 0,045 & 0,03 & 2,09 \\
\hline
\end{tabular}

Berdasarkan tabel 5., dapat diinterpretasikan sebagai berikut:

Berdasarkan pengetahuan, TFU antara kelompok intervensi dengan kelompok kontrol terdapat beda rata-rata 0,706 dengan signifikansi 0,025. TFU antara kelompok intervensi dengan kelompok tanpa perlakuan terdapat beda rata-rata 1,706 dengan signifikansi 0,000 . TFU antara kelompok kontrol dengan kelompok tanpa perlakuan terdapat beda rata-rata 1,000 dengan signifikansi 0,002. Berdasarkan nilai signifikansi kurang dari 0,05 maka dapat disimpulkan bahwa secara signifikan perbedaan pengetahuan tentang menyusui ASI on demand paling besar antara kelompok intervensi, dan kelompok tanpa perlakuan.

Berdasarkan sikap, TFU antara kelompok intervensi dengan kelompok kontrol terdapat beda rata-rata 0,706 dengan signifikansi 0,066 . TFU antara kelompok intervensi dengan kelompok tanpa perlakuan terdapat beda rata-rata 1,588 dengan signifikansi 0,000. TFU antara kelompok kontrol dengan kelompok tanpa perlakuan terdapat beda rata-rata 0,882 dengan signifikansi 0,023 . Berdasarkan nilai signifikansi maka dapat disimpulkan bahwa secara signifikan perbedaan sikap terhadap menyusui on demand paling besar antara kelompok intervensi dan kelompok tanpa perlakuan.

Berdasarkan perilaku, TFU antara kelompok intervensi dengan kelompok kontrol terdapat beda rata-rata 0,176 dengan signifikansi 0,733. TFU antara kelompok intervensi dengan kelompok tanpa perlakuan terdapat beda rata-rata 1,235 dengan signifikansi 0,020. TFU antara kelompok kelompok kontrol dengan kelompok tanpa perlakuan terdapat beda rata-rata 1,059 dengan signifikansi 0,045. Berdasarkan nilai signifikansi maka dapat disimpulkan bahwa secara signifikan perbedaan perilaku menyusui on demand paling besar antara kelompok intervensi dengan kelompok tanpa perlakuan.

Berdasarkan tabel 5 dapat disimpulkan bahwa ada Perbedaan involusi uteri pada kelompok konseling, leaflet dan tanpa perlakuan dengan kovarian pengetahuan, sikap dan perilaku pada akseptor IUD post plasenta 


\section{Analisis multivariat}

Tabel 6

Hasil Uji Ancova pengaruh konseling tentang menyusui on demand terhadap involusi uteri pada akseptor IUD post plasenta

\begin{tabular}{lrrrr}
\hline Sumber & df & \multicolumn{1}{c}{ Sean } \\
Corrected Model & 5 & 0,463 & 3,084 & 0,018 \\
Intercept & 1 & 15,146 & 100,881 & 0,000 \\
pengetahuan & 1 & 0,029 & 0,193 & 0,663 \\
sikap & 1 & 0,158 & 1,055 & 0,310 \\
perilaku & 1 & 0,044 & 0,292 & 0,592 \\
kelompok & 2 & 0,895 & 5,958 & 0,005 \\
\hline \multicolumn{5}{l}{ R Squared $=.255$ (Adjusted R Squared $=.172)$}
\end{tabular}

Berdasarkan tabel 6. dapat diinterpretasikan sebagai berikut:

1. Pada kolom Corrected Model didapatkan nilai mean square 0,463 nilai $F$ 3,084 dengan signifikansi ( $p$ value) 0,018 lebih kecil dari 0,05 sehingga dapat disimpulkan bahwa secara simultan (bersama-sama) variabel kelompok, pengetahuan, sikap dan perilaku berpengaruh terhadap involusi uteri.

2. Pada kolom Interceps didapatkan nilai mean square 15.146 nilai $F 100.881$ dengan signifikansi ( $p$ value) 0,000 lebih kecil dari 0,05 sehingga dapat disimpulkan bahwa nilai variabel dependen (involusi uteri) dapat berubah sebesar 0,463 meski tanpa dipengaruhi keberadaan covariat dan peubah bebas (variabel kelompok, pengetahuan, sikap dan perilaku).

3. Pada kolom pengetahuan didapatkan nilai mean square 0,029 nilai $\mathrm{F}$ 0,193 dengan signifikansi (p value) 0,663 lebih besar dari 0,05 sehingga dapat disimpulkan bahwa pengetahuan tidak berpengaruh terhadap involusi uteri.

4. Pada kolom sikap didapatkan nilai mean square 0,158 nilai $F$ 1,055 dengan signifikansi ( $p$ value) 0,310 lebih besar dari 0,05 sehingga dapat disimpulkan bahwa sikap tidak berpengaruh terhadap involusi uteri.

5. Pada kolom perilaku didapatkan nilai mean square 0,044 nilai $F$ 0,292 dengan signifikansi ( $p$ value) 0,592 lebih besar dari 0,05 sehingga dapat disimpulkan bahwa perilaku tidak berpengaruh terhadap involusi uteri.

6. Nilai Adjusted R Squared 0,172 menunjukkan besarnya pengaruh konseling terhadap involusi uteri sebesar $17,2 \%$ sehingga ada faktor lain sebesar $82,8 \%$ yang mempengaruhi involusi uteri.

Berdasarkan tabel 6 dapat disimpulkan bahwa pemberian informasi ASI on demand baik melalui konseling maupun leaflet mempengaruhi pengetahuan, sikap dan perilaku menyusui on demand, dimana responden yang diberikan informasi tentang ASI on demand memiliki pengetahuan, sikap dan perilaku yang lebih baik dibandingkan responden yang tidak diberi perlakuan.

Pemberian informasi ASI on demand baik melalui konseling maupun leaflet mempengaruhi pengetahuan, sikap dan perilaku menyusui on demand, dimana responden yang diberikan informasi tentang ASI on demand memiliki pengetahuan, sikap dan perilaku yang lebih baik dibandingkan responden yang tidak diberi perlakuan.

Adanya pengaruh konseling menyusui on demand terhadap involusi uteri akseptor IUD tentang menyusui on dmeand menunjukkan adanya perubahan yang terjadi pada responden sebelum dan setelah dilakukan konseling menyusui on demand. Hasil penelitian ini didukung oleh penelitian sebelumnya yang dilakukan oleh (Astrina, 2010) menyatakan bahwa ada pengaruh yang signifikan antara pemberian konseling terhadap peningkatan tingkat pengetahuan $(\mathrm{p}<0,016)$. Penelitian Sofiyana (2013) menunjukkan ada perbedaan antara pengetahuan dan sikap dan perilaku ibu sebelum dan setelah konseling dimana setelah konseling pengetahuan ibu meningkat sebesar $34,6 \%$, sedangkan sikap ibu meningkat sebesar 57,7\%. Peningkatan perilaku ibu setelah konseling menjadi baik ditunjukkan sebagian besar ibu menerapkan anjuran yang diberikan oleh konselor.

Penelitian ini didukung penelitian Afriani (2018) menunjukkan bahwa pengetahuan dan sikap memiliki pengaruh yang bermakna terhadap pemberian ASI secara on demand. Menurut Notoatmodjo (2015) pengetahuan merupakan factor dominan yang mempengaruhi perilaku seseorang, dimana seseorang akan berperilaku sesuai dengan pengetahuan yang dimilikinya. Perilaku terjadi setelah adanya informasi yang diterima, dimana informasi tersebut akan mempengaruhi sikap. Sikap yang menerima informasi akan diwujudkan dalam perilaku.

Notoatmodjo (2015) dalam teori HBM menjelaskan perilaku sebagai hasil proses informasi rasional dan menekankan pada kognisi individu, model ini sering kali dipertimbangkan sebagai kerangka utama dalam perilaku yang berkaitan dengan kesehatan manusia. Individu akan mengambil tindakan untuk menghindarkan, memeriksa atau mengendalikan kondisi kesehatan buruk jika mereka memandang rentan terhadap kondisi itu, jika mereka percaya bahwa tindakan tertentu yang tersedia akan menguntungkan dalam mengurangi kerentanan atau keparahan kondisi, dan jika mereka percaya bahwa hambatan yang terantisipasi untuk mengambil tindakan dipertimbangkan dengan keuntungan. HBM berhubungan dengan aspek kesehatan negatif yaitu perilaku seseorang ketika terancam suatu penyakit. Namun ada pula kemungkinan motivasi kesehatan positif yang meliputi perilaku mau untuk berobat. Perilaku adalah sebuah hasil dari sekumpulan persepsi, dan persepsi-persepsi ini memprediksi kemungkinan 
seseorang akan berperilaku. Persepsi tersebut adalah persepsi seseorang terhadap kemudahan kemungkinan terkena penyakit, persepsi seseorang terhadap benefits/ untung ruginya melakukan perilaku tersebut, persepsi seseorang terhadap pembiayaan bila melakukan perilaku tersebut dan tanda-tanda seseorang berperilaku/ bertindak.

Hasil penelitian ini memberikan kesimpulan bahwa pemberian konseling terhadap akseptor KB IUD post plasenta berpengaruh terhadap involusi uteri. Penelitian ini sesuai dengan penelitian (Berta, 2012) menunjukkan bahwa terdapat pengaruh konseling terhadap sikap PUS dalam pemakaian alat kontrasepsi IUD. Demikian juga dengan penelitian (Nurul, 2013) menunjukkan bahwa terdapat pengaruh konseling terhadap sikap PUS dalam pemakaian alat kontrasepsi IUD.

Adanya perbedaan rata-rata TFU antara kelompok intervensi, kelompok kontrol dan kelompok tanpa perlakuan disebabkan karena adanya perbedaan pemahaman dan pengetahuan tentang ASI on demand sehingga berbeda pula dalam memberikan ASI pada bayinya. Penelitian yang dilakukan Marati (2018) membuktikan bahwa ada hubungan yang antara menyusui eksklusif dengan involusi uteri dimana Ibu yang melaksanakan menyusui eksklusif mempunyai peluang 33 kali mengalami kontraksi uterus baik dibandingkan ibu yang tidak melaksanakan menyusui eksklusif

Proses menyusui membantu mempercepat pengembalian rahim kebentuk semula dan mengurangi perdarahan. Hal ini disebabkan adanya isapan bayi pada payudara dilanjutkan melalui saraf ke kelenjar hipofise di otak yang mengeluarkan hormon oksitosin. Oksitosin selain bekerja untuk mengkontraksi saluran ASI pada kelenjar air susu juga merangsang uterus untuk berkontraksi sehingga mempercepat involusio uteri.

Adanya perbedaan involusi uteri pada kelompok intervensi kelompok kontrol dan kelompok tanpa perlakuan yang disebabkan karena adanya perbedaan pengetahuan, sikap dan perilaku menyusui on demand yang disebabkan adanya pebedaan perlakuan. Responden yang diberikan perlakuan konseling akan memiliki pengetahuan tinggi, sikap dan perilaku positif kemudian menyusui secara on demand sehingga involusinya lebih cepat. Responden yang diberikan leaflet akan memiliki pengetahuan, sikap dan perilaku sesuai dengan pemahamannya terhadap informasi yang diterima kemudian menerapkannya dalam perilaku menyusui on demand sesuai dengan pemahamannya sehingga involusi uteri yang dialaminya sesuai dengan intensitasnya menyusui on demand. Responden yang tidak diberikan perlakuan akan menyusui bayinya sesuai naluri keibuannya tanpa memperhatikan kebutuhan bayinya sehingga involusi uterinya akan lebih lambat dibandingkan dengan kelompok yang diberi konseling dan diberi leaflet.

\section{KESIMPULAN DAN REKOMENDASI}

Berdasarkan hasil penelitian dapat disimpulkan: terdapat pengaruh konseling tentang menyusui on demand terhadap involusi uteri pada akseptor IUD post plasenta. Ada perbedaan involusi uteri pada kelompok konseling, leaflet dan tanpa perlakuan pada akseptor IUD post plasenta. Ada perbedaan involusi uteri pada kelompok konseling, leaflet dan tanpa perlakuan dengan kovarian pengetahuan, sikap dan perilaku pada akseptor IUD post plasenta.

\section{REFERENSI}

Astrina, K. M. (2010) Pengaruh Konseling Terhadap Pengetahuan Dan Pemilihan Alat Kontrasepsi Oleh Akseptor $\mathrm{Kb} \quad \mathrm{Di}$ Lingkungan Ii Kelurahan Sumber Jaya Kecamatan Siantar Martoba Pematangsiantar Tahun 2010. Medan: Universitas Sumatera Utara.

Berta (2012) Pengaruh Konseling Terhadap Sikap Pus Dalam Pemakaian Alat Kontrasepsi IUD. Medan: Universitas Sumatera Utara.

BKKBN (2013) Laporan BKKBN tahun 2013. Jakarta: BKKBN.

BKKBN (2018) International Conference on Family Planning (ICFP), Kigali Convention Centre. Jakarta: BKKBN.

BPS (2016) Potret Awal Tujuan Pembangunan Berkelanjutan (Sustainable Development Goals) di Indonesia. Jakarta: BPS Pusat.

DIY, P. (2017) Profil Kesehatan Provinsi Di Yogyakarta Tahun 2017. Yogyakarta: Dinas Kesehatan.

Kemenkes, RI. (2014) 'PMK No.97 Tahun 2014 Tentang Pelayanan Kesehatan', Artikel, p. [cited 2018 Jan 7]; p.3-8.

Kittur, S. (2012) 'Enhancing contraceptive usage by post-placental intrauterine contraceptive devices (PPIUCD) insertion with evaluation of safety, efficacy, and expulsion', International Journal of Reproduction, Contraception, Obstetrics and Gynecology, 1(1), pp. 26-32.

M. Somesh, S. Rupali, S. Swati, M. Jose, M. M. (2014) 'Invitro Comparative Study on 
Antimicrobial Activity of five Extract of Few Citrus Fruit: Peel \& Pulp vs Gentamicin', Australian Journal of Basic and Applied Sciences, 9(1), pp. 165-173.

Machiyama, Kazuyo and John, C. (2014) 'Unmet Need for Family Planning in Ghana: The Shifting Contributions of Lack of Access and Attitudinal Resistance', Studies in Family Planning, 45(2), pp. 203-226.

Marzuki (2018) ASEAN StatisticalReport on MillenniumDevelopment Goals 2017. Jakarta.: The ASEAN Secretariat.

Munayarokh (2015) 'Proses Involusio Uterus pada Ibu yang Melaksanakan dan Tidak Melaksanakan Senam Nifas di Bidan Praktek Mandiri', Jurnal Riset Kesehatan, 4(1).

Notoatmodjo, S. (2015) Ilmu Kesehatan Masyarakat Prinsip-prinsip Dasar. Jakarta: Rineka Cipta.

Prawirohardjo, S. (2010) Buku Acuan Nasional Pelayanan Kesehatan. Maternal dan Neonata. Jakarta: Bina Pustaka Sarwono Prawirohardjo.

Saleha, S. (2013) Asuhan Kebidanan 3. Jakarta: Rineka Cipta.

Sofiyana, D., (2013) Perbedaan Pengetahuan, Sikap Dan Perilaku Ibu Sebelum Dan Setelah Konseling Gizi Pada Balita Gizi Buruk, Journal of Nutrition College, Volume 2, Nomor 1, Tahun 2013, Halaman 134-144 . Online di : http://ejournals1.undip.ac.id/index.php/jnc

Sunarsih, V. N. L. D. \& T. (2013) Asuhan Kebidanan pada Ibu Nifas. Jakarta: Medika Salemba.

Wahyuningsih, E. and Sawitri, E. (2017) 'Pengaruh KB IUD Pasca Salin ( Intracaesarian Iud ) terhadap Proses Involusi Uteri pada Ibu Nifas', pp. 311-320.

WHO (2015) 'Trends in Maternal Mortality: 1990 to 2015', Geneva: WHO, UNICEF. UNFPA, and The World Bank. 